\title{
DETERMINAN STRUKTUR MODAL PADA PERUSAHAAN PROPERTY AND REAL ESTATE DI INDONESIA
}

\author{
I Putu Adi Sumardika ${ }^{1}$ \\ Luh Gede Sri Artini ${ }^{2}$ \\ ${ }^{1,2}$ Fakultas Ekonomi dan Bisnis Universitas Udayana (Unud), Bali, Indonesia \\ email: adisumardika888@gmail.com
}

\begin{abstract}
ABSTRAK
Struktur modal merupakan suatu hal yang penting untuk diperhatikan oleh perusahaan untuk menghindari terjadinya financial difficulties serta potensi kebangkrutan. Penelitian ini bertujuan untuk mengetahui pengaruh profitabilitas, stuktur aktiva, dan pertumbuhan perusahaan terhadap struktur modal. Penelitian ini dilakukan pada perusahaan sub sektor property and real estate yang terdaftar di Bursa Efek Indonesia selama tahun 2014 - 2018. Jumlah sampel yang digunakan dalam penelitian ini berjumlah 27 perusahaan dengan periode pengamatan selama 5 tahun. Teknik analisis yang digunakan adalah analisis regresi linear berganda. Hasil penelitian menunjukkan bahwa profitabilitas tidak berpengaruh signifikan terhadap struktur modal, namun struktur aktiva dan pertumbuhan perusahaan berpengaruh positif dan signifikan terhadap struktur modal.
\end{abstract}

Kata kunci: struktur modal, profitabilitas, struktur aktiva, pertumbuhan perusahaan.

\begin{abstract}
Capital structure is an important thing to consider by companies in order to avoid financial difficulties and the potential of bankruptcy. This study aims to determine the effect of profitability, asset structure, and company growth towards capital structure. This research was conducted on property and real estate companies listed in Indonesia Stock Exchange during 2014 - 2018. The number of samples used in this study are 27 companies with an observation period of 5 years. The analysis technique used is multiple linear regression analysis. The results showed that profitability has no significant effect on capital structure, but asset structure and company growth have positive and significant effect on capital structure.
\end{abstract}

Keywords: capital structure, profitability, asset structure, company growth. 


\section{PENDAHULUAN}

Indonesia merupakan negara berkembang yang memiliki potensi pertumbuhan ekonomi di masa depan. Pertumbuhan ekonomi dapat dilihat dari berkembangnya usaha yang berasal dari industri berbeda-beda, baik berskala kecil maupun besar. Perkembangan dalam dunia usaha dapat menciptakan persaingan yang ketat dikarenakan perusahaan akan meningkatkan kemampuannya dalam menjalankan aktivitas bisnis agar mampu bersaing dengan perusahaan lain. Salah satu faktor penting yang perlu dipertimbangkan dalam menjalankan bisnis adalah modal. Perusahaan sangat memerlukan sumber daya finansial dalam menjalankan bisnisnya. Perusahaan yang kekurangan modal akan mengalami kesulitan dalam membiayai aktivitasnya serta akan menjadi hambatan bagi perusahaan untuk berkembang, maka dari itu perusahaan harus menentukan besarnya modal yang dibutuhkan untuk membiayai aktivitas bisnisnya (Maryanti, 2016).

Keputusan pendanaan (financing decision) menjadi suatu hal yang penting yang harus diperhatikan oleh perusahaan dalam kaitannya dengan kebutuhan modal perusahaan. Menurut Wiagustini et al. (2017), keputusan pendanaan merupakan keputusan keuangan dalam perusahaan yang berkaitan dengan aktivitas pembelanjaan atau pembiayaan investasi. Keputusan pendanaan menyangkut halhal seperti sumber dana perusahaan serta analisis biaya modal yang digunakan perusahaan.

Setiap perusahaan dapat menggunakan sumber yang berbeda dalam memperoleh modal untuk menjalankan bisnisnya. Menurut Kabeer \& Rafique (2018), pada umumnya terdapat 2 sumber modal perusahaan yaitu utang dan ekuitas. Utang dapat diperoleh melalui penerbitan obligasi atau wesel jangka panjang, sedangkan ekuitas dapat diperoleh melalui tiga sumber utama yaitu laba ditahan, saham biasa, dan saham preferen. Hadi et al. (2018) juga menyatakan bahwa perusahaan dapat memperoleh modal yang berasal dari dalam perusahaan itu sendiri (internal financing) seperti laba ditahan serta modal yang berasal dari luar perusahaan (external financing) seperti utang dan ekuitas. Perusahaan cenderung lebih memilih modal yang berasal dari dalam perusahaan dibandingkan dengan modal yang berasal dari luar perusahaan.

Setiap keputusan yang diambil oleh perusahaan dalam menggunakan sumber dana memiliki biaya-biaya tersendiri yang juga harus diperhatikan oleh perusahaan. Kythreotis et al. (2018) menyatakan bahwa adapun komponen biaya modal yang perlu diperhatikan oleh perusahaan diantaranya yaitu biaya saham biasa (cost of common stock), biaya saham preferen (cost of preferred stock), dan biaya utang (cost of debt). Tujuan perusahaan menghitung besarnya biaya modal yang timbul dari masing-masing sumber dana adalah untuk memilih metode pendanaan dengan biaya modal yang minimum.

Perusahaan tidak hanya menggunakan satu sumber dana untuk menjalankan aktivitasnya, sehingga setiap perusahaan akan membentuk suatu struktur modal. Struktur modal menurut Sartono (2014:225) merupakan perimbangan jumlah utang jangka pendek yang bersifat permanen, utang jangka panjang, saham preferen, dan saham biasa yang digunakan oleh perusahaan. Struktur modal menjadi suatu hal yang penting untuk diperhatikan karena jika struktur modal sebuah perusahaan tidak optimal atau perusahaan gagal dalam menentukan komposisi struktur 
modalnya dengan baik, maka perusahaan tersebut akan menghadapi financial difficulties serta akan berpotensi mengalami kebangkrutan (Wiagustini et al., 2017). Suatu perusahaan dikatakan memiliki struktur modal yang optimal (optimal capital structure) apabila struktur modal perusahaan tersebut dapat memaksimumkan nilai perusahaan yang tercermin melalui harga saham. Pendekatan tradisional dari teori struktur modal mengasumsikan bahwa perusahaan akan menurunkan biaya modalnya dan meningkatkan nilai total perusahaannya melalui penggunaan leverage keuangan secara hati-hati.

Struktur modal merupakan salah satu topik yang kontroversial dalam kaitannya dengan corporate finance. Studi tentang struktur modal mulai berkembang setelah publikasi penelitian yang dilakukan oleh Modigliani \& Miller di tahun 1958 dengan judul "Irrelevancy Theory of Capital Structure" (Tandya, 2015). Penelitian tersebut menyatakan bahwa pada perfect capital market, struktur modal tidak akan mempengaruhi nilai perusahaan. Beberapa asumsi dari penelitian tersebut dianggap tidak realistis sehingga pada tahun 1963, Modigliani \& Miller kembali memperbaharui teori struktur modal dengan menambahkan efek pajak dan hal tersebut membuat struktur modal memiliki hubungan dengan nilai perusahaan (Deviani \& Sudjarni, 2018). Terdapat beberapa teori lain yang menyangkut tentang struktur modal diantaranya yaitu trade-off theory dan pecking order theory (Ngjeliu, 2018).

Struktur modal dapat diukur dengan rasio leverage salah satunya yaitu debt to equity ratio (DER). Debt to equity ratio (DER) merupakan rasio keuangan yang digunakan untuk mengetahui proporsi penggunaan ekuitas dan utang untuk membiayai aset perusahaan (Ulzanah \& Murtaqi, 2015). Nilai DER yang tinggi menandakan bahwa perusahaan menggunakan utang yang lebih banyak dibandingkan ekuitas. Perusahaan yang menggunakan lebih banyak hutang cenderung memiliki risiko yang lebih tinggi dibandingkan perusahaan yang menggunakan utang dalam jumlah yang lebih rendah. Berdasarkan perspektif pecking order theory, perusahaan lebih menyukai modal yang berasal dari dalam perusahaan (internal financing) seperti ekuitas, dibandingkan dengan modal yang berasal dari luar perusahaan (external financing) dikarenakan risiko yang lebih rendah.

Terdapat beberapa faktor yang dapat mempengaruhi struktur modal perusahaan. Brigham \& Houston (2014:188) menyatakan bahwa terdapat 12 faktor yang cenderung diperhatikan oleh perusahaan dalam hal menentukan struktur modal seperti stabilitas penjualan, struktur aset, leverage operasi, tingkat pertumbuhan, profitabilitas, pajak, control, sikap manajemen, sikap pemberi pinjaman dan lembaga pemeringkat, kondisi pasar, kondisi internal perusahaan, dan fleksibilitas keuangan. Sartono (2014:248) menyatakan terdapat 7 faktor yang mempengaruhi struktur modal perusahaan diantaranya yaitu tingkat penjualan, struktur aset, tingkat pertumbuhan perusahaan, profitabilitas, variabel laba dan perlindungan pajak, skala perusahaan, serta kondisi internal perusahaan dan ekonomi makro. Diantara faktor-faktor yang mempengaruhi struktur modal, terdapat 3 faktor yang memiliki pengaruh signifikan sesuai dengan hasil penelitian yang ditemukan oleh Vuran et al. (2017), Sofat \& Singh (2017), dan Nnadi (2016). 
Variabel-variabel tersebut diantaranya profitabilitas, struktur aktiva, dan pertumbuhan perusahaan.

Faktor pertama yang dapat mempengaruhi struktur modal perusahaan adalah profitabilitas. Profitabilitas dapat diartikan sebagai kemampuan perusahaan dalam mencapai keuntungannya. Semakin besar tingkat profitabilitas suatu perusahaan akan menunjukkan kinerja manajemen yang baik dalam mengelola keuangan dan meningkatkan kesejahteraan pemegang saham (Violita \& Sulasmiati, 2017). Berdasarkan perspektif pecking order theory, semakin tinggi profitabilitas perusahaan cenderung tidak meningkatkan struktur modalnya (Juliantika \& Rusmala, 2016). Profitabilitas dapat diukur dengan beberapa rasio yang berbeda salah satunya yaitu rasio return on assets (ROA). Return on assets (ROA) merupakan salah satu cara untuk menilai kinerja keuangan perusahaan dengan membandingkan laba bersih perusahaan dengan total asset yang dimiliki perusahaan (Bhawa \& Dewi, 2015).

Terdapat hasil penelitian yang tidak konsinten terkait pengaruh profitabilitas terhadap struktur modal perusahaan sehingga menarik untuk diteliti kembali. Penelitian yang dilakukan oleh Vuran et al. (2017) pada perusahaan manufaktur, merchandising, dan servis yang terdaftar di Istanbul Stock Exchange (ISE) menunjukkan hasil bahwa profitabilitas berpengaruh negatif dan signifikan terhadap struktur modal pada ketiga jenis perusahaan tersebut. Semakin tinggi tingkat profitabilitas suatu perusahaan, maka semakin sedikit proporsi utang yang digunakan oleh perusahaan. Pendapat tersebut juga sesuai dengan temuan penelitian yang dilakukan oleh Kythreotis et al. (2018), Nnadi (2016), dan Ngjeliu (2018). Namun hasil lain ditemukan pada penelitian yang dilakukan oleh Apsari \& Dana (2018), Dewi dkk. (2017), Sofat \& Singh (2017) yang menunjukkan profitabilitas berpengaruh positif dan signifikan terhadap struktur modal perusahaan.

Faktor kedua yang mempengaruhi struktur modal perusahaan adalah struktur aktiva. Struktur aktiva merupakan proporsi antara aktiva tetap dengan total aktiva yang dimiliki oleh perusahaan (Ahmad dkk., 2017). Struktur aktiva juga merupakan hal yang penting untuk diperhatikan oleh perusahaan yang cenderung menggunakan lebih banyak utang. Berdasarkan perspektif pecking order theory, aktiva dapat digunakan sebagai jaminan perusahaan dalam mengajukan pinjaman serta akan mengurangi dampak asimetri informasi pada perusahaan. Jaminan yang berasal dari aktiva perusahaan akan meningkatkan kepercayaan kreditur untuk memberikan pinjaman utang kepada perusahaan.

Banyak penelitian menunjukkan hasil yang berbeda terkait pengaruh antara struktur aktiva dan struktur modal perusahaan. Penelitian yang dilakukan oleh Sofat \& Singh (2017) pada perusahaan manufaktur di India menunjukkan hasil bahwa struktur aktiva berpengaruh positif dan signifikan dengan struktur modal perusahaan. Hasil tersebut kemudian didukung oleh penelitian yang dilakukan oleh M'ng et al. (2017), Nnadi (2016), Berkman et al. (2016), dan Gwatidzo et al. (2016) yang juga menunjukkan hasil positif dan signifikan antara struktur aktiva dan struktur modal perusahaan. Namun hasil lain ditemukan oleh Acaravci (2015), Alipour et al. (2015) dengan hasil yang menunjukkan pengaruh negatif dan signifikan antara struktur aktiva dan struktur modal perusahaan. 
Faktor ketiga yang mempengaruhi struktur modal perusahaan adalah tingkat pertumbuhan perusahaan. Pertumbuhan perusahaan merupakan kemampuan perusahaan untuk meningkatkan ukuran perusahaannya yang tercermin dari peningkatan aktiva (Maryanti, 2016). Pertumbuhan perusahaan dalam perspektif pecking order theory memiliki pengaruh positif terhadap struktur modal (Sudarmika \& Sudirman, 2015). Perusahaan yang memiliki pertumbuhan yang cepat sebaiknya lebih mengandalkan modal eksternal dibandingkan modal internal, sehingga kebutuhan modalnya dapat terpenuhi. Penelitian yang membuktikan pengaruh positif dan signifikan antara pertumbuhan perusahaan dan struktur modal dilakukan oleh Vuran et al. (2017), Ranitasari dan Maktukhah (2018), Karacaer et al. (2016), Dewi \& Candradewi (2018), serta Daskalakis et al. (2014). Hasil yang berbeda diungkapkan oleh Alipour et al. (2015), Ariyani dkk. (2018), dan Deviani \& Sudjarni (2018) yang mengungkapkan bahwa pertumbuhan perusahaan berpengaruh negatif dan signifikan terhadap struktur modal.

Property and real estate merupakan salah satu sektor perusahaan yang memiliki peran penting dalam menyumbang pertumbuhan ekonomi nasional, namun ternyata sektor ini hanya tumbuh dikisaran angka $3.5 \%$ selama 5 tahun terakhir dan angka tersebut berada jauh di bawah pertumbuhan ekonomi nasional yang berkisar pada angka 5\% (detikFinance, 2019). Berdasarkan data dari Badan Pusat Statistik (BPS) pada tahun 2018, kontribusi sektor property and real estate terhadap Produk Domestik Bruto (PDB) pada triwulan 3 tahun 2018 hanya sebesar 2.67\%. Angka tersebut menurun dari triwulan 3 tahun 2017 yang menunjukkan kontribusi sektor property and real estate adalah sebesar $2.74 \%$ terhadap PDB.

Lemahnya pertumbuhan sektor property and real estate membuat perusahaan dalam sektor ini perlu untuk memperhatikan struktur modalnya agar mampu membiayai kebutuhan investasi perusahaan. Struktur modal menjadi suatu hal yang penting bagi perusahaan property and real estate dikarenakan perusahaan property and real estate cenderung melakukan banyak investasi pada aktiva tetap seperti tanah dan gedung, sehingga memerlukan modal yang cukup besar dan perlu membentuk struktur modal yang optimal. Terdapat fakta menarik terkait struktur modal perusahaan property and real estate selama periode 2014 - 2018 sehingga menarik untuk diteliti.

Berdasarkan data pada Gambar 1 dapat dilihat bahwa persentase rata-rata struktur modal perusahaan property and real estate yang diukur dengan debt to equity ratio mengalami fluktuasi selama periode 2014 - 2018. Terjadi peningktan pada struktur modal perusahaan property and real estate pada tahun 2015 dengan rata-rata persentase nilai debt to equity ratio (DER) sebesar $85.78 \%$ yang dimana angka tersebut meningkat dari tahun sebelumnya yang hanya sebesar $84.78 \%$. Mulai tahun 2015 - 2018, nilai debt to equity ratio (DER) perusahaan property and real estate terus mengalami penurunan hingga mencapai angka $78.26 \%$ pada tahun 2018. Tren penurunan nilai debt to equity ratio (DER) pada perusahaan property and real estate tersebut menunjukkan fenomena bahwa perusahaan property and real estate mulai mengurangi penggunaan utang dalam struktur modalnya. 


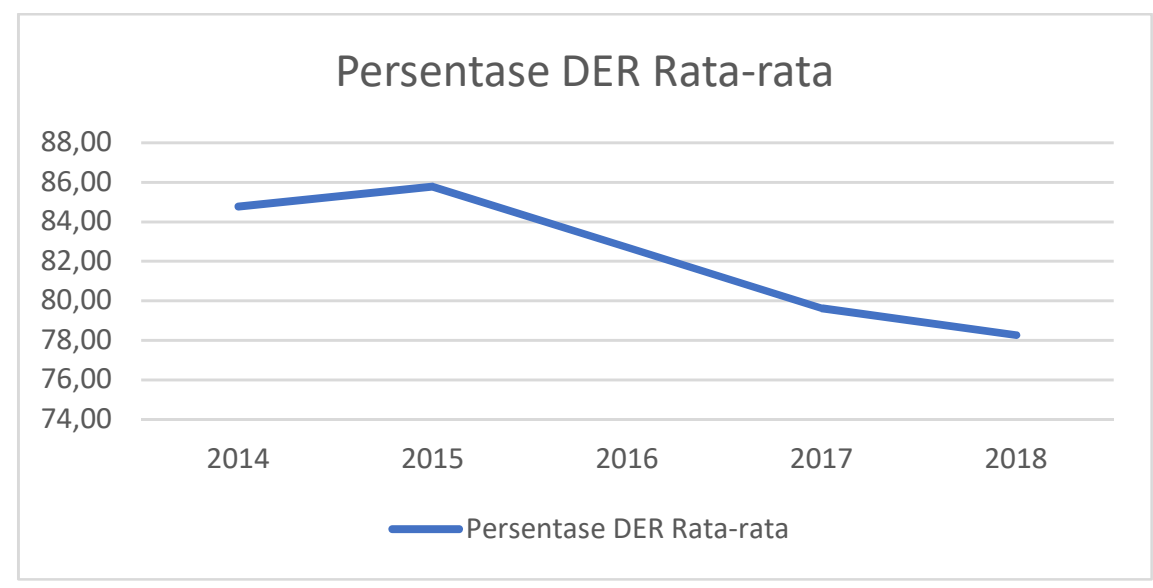

\section{Gambar 1. Persentase Debt to Equity Ratio Perusahaan Property and Real Estate di Bursa Efek Indonesia selama Periode 2014 - 2018}

Sumber: Data Diolah, 2019

Berdasarkan latar belakang masalah yang telah diuraikan, dapat disusun rumusan masalah sebagai berikut: 1) Bagaimana pengaruh profitabilitas terhadap struktur modal perusahaan? 2) Bagaimana pengaruh struktur aktiva terhadap struktur modal perusahaan? 3) Bagaimana pengaruh tingkat pertumbuhan perusahaan terhadap struktur modal perusahaan?

Tujuan penelitian ini adalah untuk menjelaskan masing-masing pengaruh antara profitabilitas, struktur aktiva, dan pertumbuhan perusahaan terhadap struktur modal perusahaan. Hasil dari penelitian ini diharapkan dapat memberikan bukti empiris terkait pengaruh profitabilitas, struktur aktiva, dan tingkat pertumbuhan perusahaan terhadap struktur modal perusahaan property and real estate di Indonesia serta dapat memberikan informasi dan bahan pertimbangan kepada manajer serta investor.

Kerangka konseptual yang menjadi acuan pembentukan hipotesis penelitian ditunjukkan pada Gambar 2.

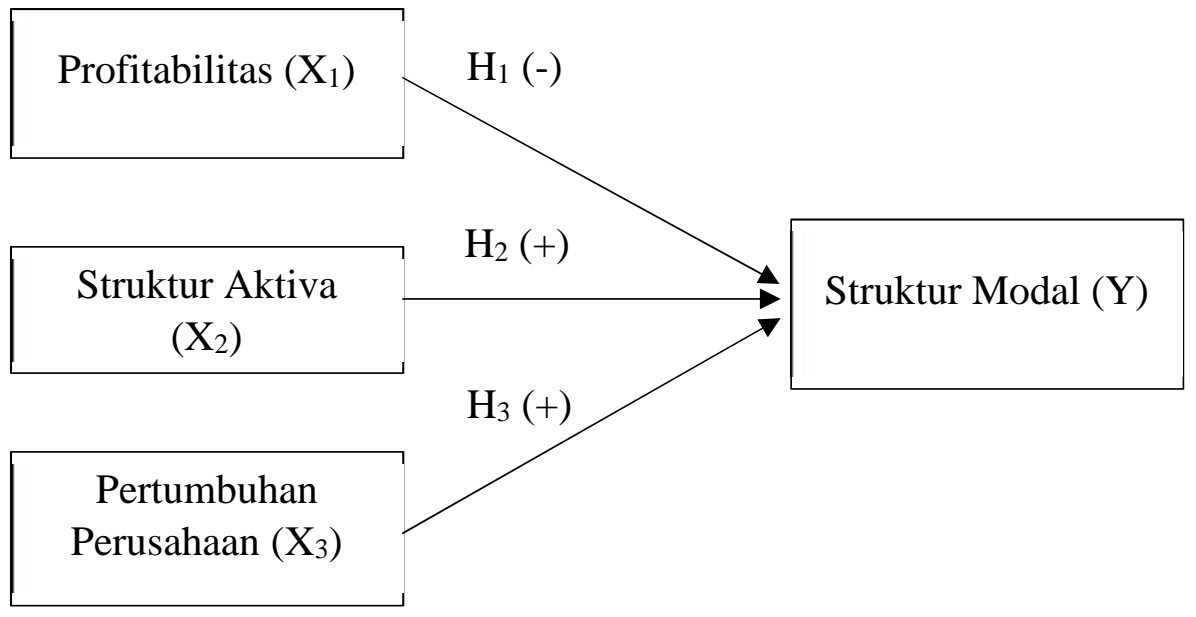

Gambar 2. Kerangka Konseptual 
Profitabilitas menunjukkan kemampuan perusahaan dalam memperoleh laba atau efektivitas pengelolaan manajemen dalam perusahaan (Wiagustini et al., 2017). Semakin besar tingkat profitabilitas suatu perusahaan akan menunjukkan kinerja manajemen yang baik dalam mengelola keuangan dan meningkatkan kesejahteraan pemegang saham (Violita \& Sulasmiati, 2017). Berdasarkan perspektif pecking order theory, profitabilitas berpengaruh negatif terhadap struktur modal karena perusahaan yang memiliki profitabilitas tinggi cenderung lebih memilih menggunakan pendanaan internal seperti retained earnings dibandingkan utang.

Penelitian yang dilakukan oleh Vuran et al. (2017) pada perusahaan manufaktur, merchandising, dan servis yang terdaftar di Istanbul Stock Exchange (ISE) menunjukkan hasil bahwa profitabilitas berpengaruh negatif dan signifikan terhadap struktur modal pada ketiga jenis perusahaan tersebut. Semakin tinggi tingkat profitabilitas suatu perusahaan, maka semakin sedikit proporsi utang yang digunakan oleh perusahaan. Hasil tersebut juga sesuai dengan temuan penelitian yang dilakukan oleh Kythreotis et al. (2018), Goh (2018), Nnadi (2016), dan Ngjeliu (2018).

$\mathrm{H}_{1}$ : Profitabilitas berpengaruh negatif dan signifikan terhadap Struktur Modal.

Menurut Ahmad dkk. (2017), struktur aktiva merupakan proporsi antara aktiva tetap dengan total aktiva yang dimiliki oleh perusahaan. Berdasarkan perspektif pecking order theory, aktiva dapat digunakan sebagai jaminan perusahaan dalam mengajukan pinjaman serta akan mengurangi dampak asimetri informasi pada perusahaan. Dengan adanya jaminan dalam mengajukan pinjaman, maka akan meningkatkan kepercayaan kreditur untuk memberikan pinjaman kepada perusahaan.

Penelitian yang dilakukan oleh Sofat \& Singh (2017) pada perusahaan manufaktur di India menunjukkan hasil bahwa terdapat pengaruh positif dan signifikan antara struktur aktiva dan struktur modal perusahaan. Perusahaan yang memiliki jumlah aktiva tetap yang lebih besar dapat menggunakannya sebagai jaminan dalam mengajukan pinjaman, sehingga akan meningkatkan kepercayaan kreditur untuk memberikan pinjaman kepada perusahaan. Hasil tersebut juga didukung oleh penelitian yang dilakukan oleh M'ng, et al. (2017), Nnadi (2016), Berkman et al. (2016), dan Gwatidzo et al. (2016) yang juga menunjukkan hasil positif dan signifikan antara struktur aktiva dan struktur modal perusahaan $\mathrm{H}_{2}$ : Struktur Aktiva berpengaruh positif dan signifikan terhadap Struktur Modal.

Pertumbuhan perusahaan merupakan kemampuan perusahaan untuk meningkatkan ukuran perusahaannya yang tercermin dari peningkatan aktiva (Maryanti, 2016). Berdasarkan perspektif pecking order theory, perusahaan yang memiliki tingkat pertumbuhan yang cepat akan lebih mengandalkan kepada modal eksternal dikarenakan pertumbuhan perusahaan akan memicu kebutuhan modal perusahaan yang semakin tinggi. Pertumbuhan perusahaan berpengaruh positif dan signifikan terhadap struktur modal. Pengaruh positif dan signifikan antara pertumbuhan perusahaan dan struktur modal diakibatkan karena pertumbuhan perusahaan akan memicu kebutuhan modal perusahaan yang semakin tinggi. Pertumbuhan perusahaan yang tinggi akan mengantisipasi adanya asimetris informasi dan diperkirakan akan menggunakan lebih banyak utang dibandingkan 
ekuitas. Pernyataan tersebut sejalan dengan penelitian yang dilakukan oleh Vuran et al. (2017), Karacaer et al. (2016), Dewi \& Candradewi (2018), serta Daskalakis et al. (2014) yang juga menunjukkan hasil bahwa pertumbuhan perusahaan berpengaruh positif dan signifikan terhadap struktur modal.

$\mathrm{H}_{3}$ : Pertumbuhan perusahaan berpengaruh positif dan signifikan terhadap Struktur Modal.

\section{METODE PENELITIAN}

Penelitian ini merupakan penelitian kuantitatif yang berbentuk asosiatif dengan tujuan untuk menganalisis hubungan antara profitabilitas, struktur aktiva, dan pertumbuhan perusahaan terhadap struktur modal. Penelitian ini dilakukan pada perusahaan sub sektor property and real estate di Bursa Efek Indonesia yang dapat diaskes melalui website www.idx.co.id. Objek dalam penelitian ini adalah struktur modal perusahaan sub sektor property and real estate yang terdaftar di Bursa Efek Indonesia pada periode 2014-2018. Variabel dependen dalam penelitian ini adalah struktur modal. Variabel bebas dalam penelitian ini yaitu: Profitabilitas $\left(\mathrm{X}_{1}\right)$, Struktur Aktiva $\left(\mathrm{X}_{2}\right)$ dan Pertumbuhan Perusahaan $\left(\mathrm{X}_{3}\right)$

Struktur modal merupakan perimbangan jumlah utang jangka pendek yang bersifat permanen, utang jangka panjang, saham preferen, dan saham biasa yang digunakan oleh perusahaan. Struktur modal pada penelitian ini diukur dengan $d e b t$ to equity ratio (DER). Debt to equity ratio merupakan rasio perbandingan total utang perusahaan dengan modal sendiri yang dimiliki oleh perusahaan sub sektor property and real estate di Bursa Efek Indonesia selama periode 2014-2018. Satuan pengukuran debt to equity ratio adalah persentase dengan rumus sebagai berikut:

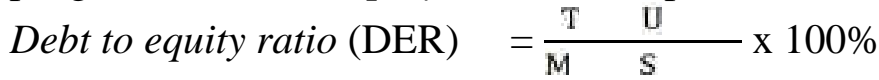

Profitabilitas merupakan kemampuan perusahaan dalam memperoleh keuntungan. Profitabilitas pada penelitian ini diukur dengan rasio return on assets (ROA) yang merupakan perbandingan laba bersih setelah pajak dengan total aktiva perusahaan seb sektor property and real estate di Bursa Efek Indonesia selama periode 2014-2018. Persentase perhitungan return on assets (ROA) adalah persentase dengan rumus sebagai berikut:

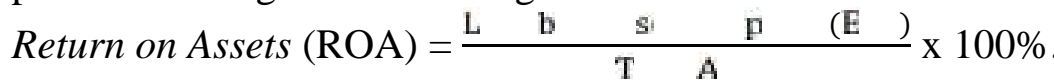

Struktur aktiva merupakan penentuan besarnya alokasi untuk masing-masing komponen aktiva perusahaan. Struktur aktiva pada penelitian ini diukur dengan fixed assets ratio yang dimana rasio ini membandingkan jumlah aktiva tetap dengan total aktiva yang dimiliki oleh perusahaan sub sektor property and real estate di Bursa Efek Indonesia selama periode 2014-2018. Satuan pengukuran fixed assets ratio adalah persentase, dengan rumus sebagai berikut:

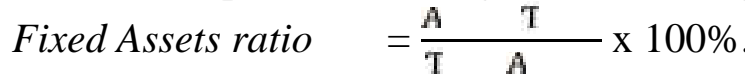

Pertumbuhan perusahaan merupakan kemampuan perusahaan untuk meningkatkan ukuran perusahaannya yang tercermin melalui peningkatan aktiva. Pertumbuhan perusahaan dalam penelitian ini dicerminkan melalui pertumbuhan total aktiva yang dimiliki oleh perusahaan sub sektor property and real estate di 
Bursa Efek Indonesia selama periode 2014-2018. Satuan pengukuran pertumbuhan aktiva perusahaan adalah persentase dengan rumus sebagai berikut:

Pertumbuhan Perusahaan $=\frac{A \quad \text { t n } n \quad t-A \quad t \text { nun } t-1}{A \quad t \text { nu } t-1} \times 100 \%$

Data kuantitatif yang digunakan dalam penelitian ini bersumber dari laporan keuangan perusahaan sub sektor property and real estate di Bursa Efek Indonesia yang diperoleh melalui website www.idx.co.id. Populasi dalam penelitian ini adalah seluruh perusahaan yang masuk ke dalam sub sektor property and real estate yang terdaftar di Bursa Efek Indonesia selama tahun 2014 - 2018. Terdapat perusahaan sub sektor property and real estate memiliki data laporan keuangan yang tidak lengkap, sehingga tidak dapat digunakan dalam penelitian. Metode penentuan sampel yang digunakan adalah sampling jenuh (sensus). Diperoleh total sampel sebanyak 27 perusahaan sub sektor property and real estate yang terdaftar di Bursa Efek Indonesia selama tahun 2014 - 2018. Penelitian ini menggunakan metode pengumpulan data observasi non partisipan. Penelitian ini dilakukan dengan pengamatan pada laporan keuangan perusahaan sub sektor property and real estate di Bursa Efek Indonesia selama periode 2014 - 2018.

\section{HASIL DAN PEMBAHASAN}

Bursa Efek Indonesia memiliki 9 jenis sektor beserta sub sektor perusahaan yang berbeda-beda. Property and Real Estate merupakan salah satu sub sektor dalam sektor Property, Real Estate, and Building Construction yang terdaftar di Bursa Efek Indonesia. Perusahaan dalam sub sektor property and real estate ini biasanya merupakan pemilik, pengembang, ataupun pengelola real estate termasuk diantaranya berupa perumahan, apartemen, serta pusat perbelanjaan. Penelitian ini menggunakan 27 perusahaan yang terdaftar ke dalam sub sektor property and real estate sebagai sampel penelitian seperti yang tercantum dalam Tabel 1.

Tabel 1.

Perusahaan Sub Sektor Property and Real Estate di Bursa Efek Indonesia selama Periode 2014 - 2018 yang Menjadi Sampel Penelitian

\begin{tabular}{cclc}
\hline No & Kode & \multicolumn{1}{c}{ Nama Perusahaan } & Tanggal IPO \\
\hline 1 & APLN & Agung Podomoro Land Tbk. & 11-Nov-10 \\
2 & ASRI & Alam Sutera Realty Tbk. & 18-Dec-07 \\
3 & BCIP & Bumi Citra Permai Tbk. & 11-Dec-09 \\
4 & BEST & Bekasi Fajar Industrial Estate Tbk. & 10-Apr-12 \\
5 & BKDP & Bukit Darmo Property Tbk. & 15-Jun-07 \\
6 & BKSL & Sentul City Tbk. & 28-Jul-97 \\
7 & BSDE & Bumi Serpong Damai Tbk. & 6-Jun-08 \\
8 & CTRA & Ciputra Development Tbk. & 28-Mar-94 \\
9 & DART & Duta Anggada Realty Tbk. & 8-May-90 \\
10 & DILD & Intiland Development Tbk. & 4-Sep-91 \\
\hline bersambung... & & &
\end{tabular}


Lanjutan Tabel 1.

\begin{tabular}{cclc}
\hline No & Kode & Nama Perusahaan & Tanggal IPO \\
\hline 11 & DUTI & Duti Pertiwi Tbk. & 2-Nov-94 \\
12 & ELTY & Bakrieland Development Tbk. & 30-Oct-95 \\
13 & EMDE & Megapolitan Developments Tbk. & 12-Jan-11 \\
14 & GAMA & Gading Development Tbk. & 11-Jul-12 \\
15 & GMTD & Gowa Makassar Tourism Development Tbk. & 11-Dec-00 \\
16 & GPRA & Perdana Gapura Prima Tbk. & 11-Oct-07 \\
17 & JRPT & Jaya Real Property Tbk. & 29-Jun-94 \\
18 & KIJA & Kawasan Industri Jababeka Tbk. & 10-Jan-95 \\
19 & LPKR & Lippo Karawaci Tbk. & 28-Jun-96 \\
20 & MDLN & Modernland Realty Ltd Tbk. & 18-Jan-93 \\
21 & MTLA & Metropolitan Land Tbk. & 20-Jun-11 \\
22 & NIRO & City Retail Developments Tbk. & 13-Sep-12 \\
23 & PWON & Pakuwon Jati Tbk. & 9-Oct-89 \\
24 & RODA & Pikko Land Development Tbk. & 22-Oct-01 \\
25 & SCBD & Danayasa Arthatama Tbk. & 19-Apr-02 \\
26 & SMDM & Suryamas Dutamakmur Tbk. & 12-Oct-95 \\
27 & SMRA & Summarecon Agung Tbk. & 7-May-90 \\
\hline
\end{tabular}

Sumber: Data Diolah, 2019

Statistik deskriptif bertujuan untuk memberikan gambaran atau deskripsi dari data-data yang telah terkumpul. Statistik deskriptif yang digunakan dalam penelitian ini diantaranya nilai minimum, maksimum, rata-rata (mean), dan standar deviasi seperti yang dapat dilihat pada Tabel 2.

Tabel 2.

Hasil Analisis Statistik Deskriptif

\begin{tabular}{lrrrrr}
\hline & N & Minimum & Maximum & \multicolumn{1}{c}{ Mean } & Std. Deviation \\
\hline $\begin{array}{l}\text { Struktur } \\
\text { Modal }\end{array}$ & 135 & 14.00 & 183.00 & 82.2259 & 43.76015 \\
$\begin{array}{l}\text { Profitabilitas } \\
\text { Struktur }\end{array}$ & 135 & -5.51 & 16.87 & 4.1484 & 4.15936 \\
$\begin{array}{l}\text { Aktiva } \\
\text { Pertumbuhan }\end{array}$ & 135 & .14 & 26.20 & 5.9886 & 5.74494 \\
$\begin{array}{l}\text { Perusahaan } \\
\text { Valid N }\end{array}$ & 135 & -16.42 & 103.74 & 9.7814 & 13.60304 \\
(listwise) & 135 & & & & \\
\hline
\end{tabular}

Sumber: Data Diolah, 2019

Struktur modal perusahaan property and real estate yang menjadi sampel penelitian ini berkisar antara 14.00 sampai 183.00 dengan nilai rata-rata sebesar 82.2259 dan standar deviasi sebesar 43.76015. Nilai rata-rata sebesar 82.2259 tersebut menunjukkan bahwa proporsi utang dalam struktur modal perusahaan 
property and real estate yang menjadi sampel penelitian ini lebih banyak dibandingkan dengan ekuitas.

Profitabilitas perusahaan property and real estate yang menjadi sampel penelitian ini berkisar antara -5.51 sampai 16.87 dengan nilai rata-rata sebesar 4.1484 dan standar deviasi sebesar 4.15936. Nilai tersebut menunjukkan bahwa profitabilitas perusahaan property and real estate yang menjadi sampel penelitian ini cenderung rendah bahkan terdapat perusahaan yang rugi yang ditunjukkan melalui nilai minimum yaitu -5.51 .

Struktur aktiva perusahaan property and real estate yang menjadi sampel penelitian ini berkisar antara 0.14 sampai 26.20 dengan nilai rata-rata sebesar 5.9886 dan standar deviasi sebesar 5.74494. Nilai tersebut menunjukkan bahwa proporsi aktiva tetap yang dimiliki oleh perusahaan property and real estate yang menjadi sampel penelitian ini cukup tinggi.

Pertumbuhan perusahaan perusahaan property and real estate yang menjadi sampel penelitian ini berkisar antara -16.42 sampai 103.74 dengan rata-rata sebesar 9.7814 dan standar deviasi sebesar 13.60304. Pertumbuhan perusahaan pada perusahaan property and real estate yang menjadi sampel penelitian cenderung cepat yang dibuktikan dengan nilai maksimum sebesar 103.74.

Analisis statistik inferensial yang digunakan dalam penelitian ini yaitu regresi linear berganda. Analisis regresi linear berganda digunakan untuk mengetahui dan memperoleh gambaran tentang pengaruh variabel independen yang akan diteliti. Analisis regresi linear berganda ini akan membantu dalam mengetahui pengaruh variabel independen dalam penelitian ini yaitu profitabilitas $\left(\mathrm{X}_{1}\right)$, Struktur Aktiva $\left(\mathrm{X}_{2}\right)$, dan Pertumbuhan Perusahaan $\left(\mathrm{X}_{3}\right)$ terhadap struktur modal $(\mathrm{Y})$. Hasil perhitungan koefisien regresi linear berganda disajikan pada Tabel 3.

Tabel 3.

Hasil Analisis Regresi Linear Berganda

\begin{tabular}{|c|c|c|c|c|c|c|}
\hline & \multirow{2}{*}{ Model } & \multicolumn{2}{|c|}{ Unstandardized Coefficients } & \multirow[t]{2}{*}{$\begin{array}{c}\text { Standardized } \\
\text { Coefficients }\end{array}$} & \multirow{2}{*}{$\mathbf{t}$} & \multirow{2}{*}{ Sig. } \\
\hline & & B & $\begin{array}{l}\text { Std. } \\
\text { Error }\end{array}$ & & & \\
\hline \multirow[t]{4}{*}{1} & (Constant) & 3.991 & .096 & & 41.589 & .000 \\
\hline & Profitabilitas & .009 & .013 & .062 & .671 & .503 \\
\hline & $\begin{array}{l}\text { Struktur } \\
\text { Aktiva }\end{array}$ & .024 & .009 & .234 & 2.737 & .007 \\
\hline & $\begin{array}{l}\text { Pertumbuhan } \\
\text { Perusahaan }\end{array}$ & .008 & .004 & .180 & 1.998 & .048 \\
\hline
\end{tabular}

Sumber: Data Diolah, 2019

Berdasarkan Tabel 3. yang menyajikan hasil analisis regresi linear berganda, dapat diperoleh persamaan regresi sebagai berikut:

$\mathrm{Y}=3.991+0.009 \mathrm{x}_{1}+0.024 \mathrm{x}_{2}+0.008 \mathrm{x}_{3}+\mathrm{e}$ 
Secara statistik hasil regresi menunjukkan bahwa apabila nilai profitabilitas, struktur aktiva, dan pertumbuhan perusahaan dianggap konstan (nol), maka nilai variabel struktur modal akan meningkat sebesar 3.991 persen.

$\beta_{1}=0.009$, artinya apabila nilai variabel profitabilitas naik sebesar satu persen, maka nilai variabel struktur modal akan meningkat sebesar 0.009 persen dengan asumsi variabel lainnya konstan (nol). $\beta_{2}=0.024$, artinya apabila nilai variabel struktur aktiva naik sebesar satu persen, maka nilai variabel struktur modal akan meningkat sebesar 0.024 persen dengan asumsi variabel lainnya konstan (nol). $\beta_{3}=0.008$, artinya apabila nilai variabel pertumbuhan perusahaan naik sebesar satu persen, maka nilai variabel struktur modal akan meningkat sebesar 0.008 persen dengan asumsi variabel lainnya konstan (nol).

Uji normalitas bertujuan untuk mengetahui distribusi data pada penelitan. Model regresi yang baik adalah yang memiliki distribusi residual yang normal atau mendekati normal. Hasil uji normalitas ditunjukkan pada Tabel 4.

Tabel 4.

Hasil Uji Normalitas

\begin{tabular}{llr}
\hline & & \multicolumn{2}{c}{$\begin{array}{c}\text { Unstandardized } \\
\text { Residual }\end{array}$} \\
\hline $\mathrm{N}$ & Mean & 135 \\
Normal Parameters & & .0000000 \\
& Std. Deviation & .56723013 \\
& Absolute & .065 \\
Most Extreme Differences & Positive & .062 \\
& Negative & -.065 \\
Test Statistic & & .065 \\
Asymp. Sig. (2-tailed) & & .200 \\
\hline Sumber: Data Diolah, 2019 & &
\end{tabular}

Berdasarkan Tabel 4. maka hasil uji normalitas Kolmogorov-Smirnov menunjukkan nilai signifikansi sebesar 0.200. Nilai tersebut lebih besar dari level of significant sebesar 0.05 , sehingga dapat disimpulkan bahwa data pada penelitian ini berdistribusi normal dan asumsi normalitas pada regresi telah terpenuhi.

Uji multikolinearitas bertujuan untuk menguji apakah terdapat korelasi antar variabel bebas (independen). Model regresi yang baik seharusnya tidak terjadi korelasi antar variabel bebas (independen), sehingga untuk mendeteksi adanya multikolinearitas dalam model regresi, dapat dilihat dari nilai tolerance dan lawannya Variance Inflation Factor (VIF). Regresi yang tidak terjadi multikolinearitas adalah regresi yang memiliki nilai VIF $<10$ dan mempunyai angka tolerance $>0.1$. Hasil uji multikolinearitas disajikan pada Tabel 5.

Berdasarkan Tabel 5. dapat diketahui bahwa variabel profitabilitas memiliki nilai tolerance sebesar 0.814 , variabel struktur aktiva memiliki nilai tolerance sebesar 0.950, dan variabel pertumbuhan perusahaan memiliki nilai tolerance sebesar 0.853. Nilai VIF variabel profitabilitas adalah sebesar 1.229, nilai VIF 
variabel struktur aktiva sebesar 1.053, dan nilai VIF variabel pertumbuhan perusahaan sebesar 1.172. Ketiga nilai tolerance dari variabel bebas tersebut lebih besar dari 0.1 dan nilai VIF lebih kecil dari 10, maka dapat disimpulkan bahwa tidak terdapat gejala multikolinearitas.

Tabel 5.

Hasil Uji Multikolinearitas

\begin{tabular}{llcc}
\hline \multirow{2}{*}{ Model } & & \multicolumn{2}{c}{ Collinearity Statistics } \\
& & Tolerance & VIF \\
\hline 1 & (Constant) & & 1.229 \\
& Profitabilitas & .814 & 1.053 \\
& Struktur Aktiva & .950 & 1.172 \\
& Pertumbuhan & .853 & \\
& Perusahaan & &
\end{tabular}

Sumber: Data Diolah, 2019

Uji Heteroskedastisitas bertujuan menguji apakah dalam metode regresi terjadi ketidaksamaan varian dari residual satu pengamatan ke pengamatan yang lain. Gejala heteroskedastisita dapat didetekni menggunakan metode Glejser yaitu dengan meregresi nilai absolut residual dari model yang diestimasi terhadap variabel bebas. Jika model regresi lebih besar tingkat signifikansinya dari 0.05 maka model regresi tidak mengandung gejala heteroskedastisitas. Hasil uji heteroskedastisitas disajikan pada Tabel 6 .

Tabel 6.

Hasil Uji Heteroskedastisitas

\begin{tabular}{|c|c|c|c|c|c|c|}
\hline \multirow[b]{2}{*}{ Model } & & \multicolumn{2}{|c|}{ Unstandardized Coefficients } & \multirow{2}{*}{$\begin{array}{c}\text { Standardized } \\
\text { Coefficients } \\
\text { Beta } \\
\end{array}$} & \multirow[b]{2}{*}{$\mathbf{t}$} & \multirow[b]{2}{*}{ Sig. } \\
\hline & & B & Std. Error & & & \\
\hline \multirow[t]{6}{*}{1} & (Constant) & 0.536 & 0.052 & & 10.305 & 0.000 \\
\hline & Profitabilitas & -0.007 & 0.007 & -0.088 & $0.919^{-}$ & 0.360 \\
\hline & Struktur & & & & - & \\
\hline & Aktiva & -0.005 & 0.005 & -0.097 & 1.093 & 0.276 \\
\hline & Pertumbuhan & & & & - & \\
\hline & Perusahaan & 0.000 & 0.002 & -0.018 & 0.193 & 0.847 \\
\hline
\end{tabular}

Berdasarkan Tabel 6. maka hasil uji heteroskedastisitas dengan uji Glejser menunjukkan nilai signifikansi masing-masing variabel bebas lebih besar dari 0.05 , sehingga dapat dinyatakan bahwa model regresi dalam penelitian ini tidak terjadi gejala heteroskedastisitas.

Uji autokorelasi bertujuan untuk menguji apakah dalam model regresi terdapat korelasi antara kesalahan pengganggu pada periode $t$ dengan kesalahan pengganggu pada periode t-1. Uji autokorlasi dapat dilakukan dengan uji DurbinWatson (Dw Test). Pengambilan keputusan tidak terjadinya gejala autokorelasi adalah apabila $\mathrm{du}<\mathrm{dw}<4$-du. Hasil uji autokorelasi disajikan pada Tabel 7. di bawah ini. 
Tabel 7.

Hasil Uji Autokorelasi

\begin{tabular}{|c|c|c|c|c|c|}
\hline Model & $\mathbf{R}$ & R Square & $\begin{array}{l}\text { Adjusted R } \\
\text { Square }\end{array}$ & $\begin{array}{l}\text { Std. Error of } \\
\text { the Estimate }\end{array}$ & $\begin{array}{l}\text { Durbin- } \\
\text { Watson }\end{array}$ \\
\hline &, $300^{\mathrm{a}}$ & ,090 & ,069 & ,57369 & 1,967 \\
\hline
\end{tabular}

Berdasarkan Tabel 7, maka dapat dilihat bahwa nilai Durbin-Watson adalah sebesar 1.967. Nilai du sebesar 1.764 dengan level of signicant sebesar 0.05 untuk $\mathrm{n}=135$ dan $\mathrm{k}=3$. Nilai Durbin Watson tersebut tidak mengalami gejala autokorelasi dikarenakan berada pada $\mathrm{du}<\mathrm{dw}<4$-du atau $1.764<1.967<2.236$.

Tabel 8.

Hasil Koefisien Determinasi

\begin{tabular}{rrrrrr}
\hline Model & R & R Square & Adjusted R Square & \multicolumn{2}{c}{$\begin{array}{c}\text { Std. Error of the } \\
\text { Estimate }\end{array}$} \\
\hline 1 &, $300^{\mathrm{a}}$ &, 090 &, 069 &, 57369 \\
\hline
\end{tabular}

Sumber: Data Diolah, 2019

Koefisien determinasi menunjukkan presentase variasi variabel dependen yang dapat dijelaskan oleh variabel independen.Berdasarkan Tabel 8, maka dapat diketahui nilai adjusted $R$ square adalah sebesar 0.069. Nilai tersebut berarti sebesar $6.9 \%$ perubahan struktur modal pada perusahaan property and real estate yang terdaftar di Bursa Efek Indonesia selama periode 2014 - 2018 dipengaruhi oleh variabel profitabilitas, struktur aktiva, dan pertumbuhan perusahaan. Sebesar $93.1 \%$ perubahan struktur modal dipengaruhi oleh variabel lain di luar model regresi.

Uji kesesuaian model digunakan untuk melihat kelayakan model penelitian dengan tujuan melihat apakah variabel bebas (independen) secara serempak mempengaruhi variabel terikat (dependen). Hasil uji kesesuaian model dapat dilihat pada regresi olahan SPSS dengan cara membandingkan tingkat signifikansi antara variabel independen dengan $\alpha=0.05$. Tabel 9. di bawah menyajikan hasil uji kesesuaian model.

Tabel 9.

Hasil Uji Kesesuaian Model

\begin{tabular}{|c|c|c|c|c|c|c|}
\hline \multicolumn{2}{|c|}{ Model } & Sum of Squares & df & Mean Square & \multirow{2}{*}{$\frac{\mathbf{F}}{4.318}$} & \multirow{2}{*}{$\frac{\text { Sig. }}{.006^{\mathrm{b}}}$} \\
\hline 1 & Regression & 4.264 & 3 & 1.421 & & \\
\hline & Residual & 43.115 & 131 & 0.329 & & \\
\hline & Total & 47.378 & 134 & & & \\
\hline
\end{tabular}

Sumber: Data Diolah, 2019

Berdasarkan Tabel 9. dapat dilihat bahwa nilai $\mathrm{F}$ hitung sebesar 4.318 dengan signifikansi sebesar 0.006. Nilai signifikansi yang lebih kecil dari $\alpha=0.05$ menunjukkan bahwa ketiga variabel bebas yaitu profitabilitas, struktur aktiva, dan pertumbuhan perusahaan secara simultan berpengaruh signifikan terhadap struktur modal. 
Uji hipotesis dilakukan untuk mengetahui pengaruh variabel bebas (independen) secara individual atau parsial terhadap variabel terikat (dependen). Tabel 10 menyajikan hasil uji hipotesis.

Tabel 10. Hasil Uji Hipotesis

\begin{tabular}{cccc}
\hline Model & $\boldsymbol{\beta}$ & Sig. & Keterangan \\
\hline Profitabilitas & .009 & .503 & Ditolak \\
Struktur Aktiva & .024 & .007 & Diterima \\
Pertumbuhan Perusahaan & .008 & .048 & Diterima \\
\hline
\end{tabular}

Sumber: Data Diolah, 2019

Nilai $\beta$ sebesar 0.009 serta nilai signifikansi uji t sebesar $0.503>\alpha=0.05$. Nilai tersebut menunjukkan bahwa profitabilitas berpengaruh positif tidak signifikan terhadap struktur modal, sehingga $\mathrm{H}_{1}$ dalam penelitian ini ditolak. Nilai $\beta$ sebesar 0.024 serta nilai signifikansi uji t sebesar $0.007<\alpha=0.05$. Nilai tersebut menunjukkan bahwa struktur aktiva berpengaruh positif dan signifikan terhadap struktur modal, sehingga $\mathrm{H}_{2}$ dalam penelitian ini diterima. Nilai $\beta$ sebesar 0.008 serta nilai signifikansi uji t sebesar $0.048<\alpha=0.05$. Nilai tersebut menunjukkan bahwa pertumbuhan parusahaan berpengaruh positif dan signifikan terhadap struktur modal, sehingga $\mathrm{H}_{3}$ dalam penelitian ini diterima.

$\mathrm{H}_{1}$ dalam penelitian ini adalah profitabilitas berpengaruh negatif dan signifikan terhadap struktur modal. Hasil pengujian berdasarkan menunjukkan variabel profitabilitas memiliki nilai $\beta$ sebesar 0.009 serta nilai signifikansi uji t sebesar $0.503>\alpha=0.05$. Nilai tersebut membuktikan bahwa profitabilitas tidak berpengaruh signifikan terhadap struktur modal perusahaan property and real estate yang terdaftar di Bursa efek Indonesia selama tahun 2014 - 2018, sehingga $\mathrm{H}_{1}$ dalam penelitian ditolak.

Hasil penelitian ini tidak mendukung hasil penelitian yang dilakukan oleh Vuran et al. (2017), Kythreotis et al. (2018), Nnadi (2016), dan Ngjeliu (2018) serta tidak sesuai dengan perspektif pecking order theory yang menyatakan bahwa perusahaan dengan profitabilitas yang tinggi akan cenderung menggunakan dana internal seperti retained earnings sebelum memutuskan untuk menggunakan utang. Profitabilitas perusahaan yang tidak mencukupi kebutuhan modalnya membuat perusahaan tetap memilih untuk menggunakan utang. Profitabilitas perusahaan property and real estate yang terdaftar di Bursa Efek Indonesia selama tahun 2014 - 2018 yang berkisar antara $-5.51 \%$ sampai $16.87 \%$ ternyata tidak berdampak banyak terhadap struktur modal perusahaan tersebut. Struktur modal perusahaan akan tetap meningkat ketika profitabilitas perusahaan mengalami fluktuasi.

$\mathrm{H}_{2}$ dalam penelitian ini adalah struktur aktiva berpengaruh positif dan signifikan terhadap struktur modal. Hasil pengujian menunjukkan variabel struktur aktiva memiliki nilai $\beta$ sebesar 0.024 serta nilai signifikansi uji t sebesar $0.007<\alpha$ $=0.05$. Nilai tersebut menunjukkan bahwa struktur aktiva berpengaruh positif dan signifikan terhadap struktur modal perusahaan property and real estate yang terdaftar di Bursa efek Indonesia selama tahun 2014 - 2018, sehingga $\mathrm{H}_{2}$ dalam penelitian ini diterima. 
Hasil pengaruh struktur aktiva terhadap struktur modal pada penelitian ini mendukung hasil penelitian yang ditemukan oleh Sofat \& Singh (2017), M'ng et al. (2017), Nnadi (2016), Berkman et al. (2016), dan Gwatidzo et al. (2016) yang juga menyatakan bahwa struktur aktiva berpengaruh positif dan signifikan terhadap struktur modal. Hasil yang membuktikan adanya pengaruh positif dan signifikan antara struktur aktiva dan struktur modal tersebut juga sejalan dengan perspektif pecking order theory yang menyatakan bahwa perusahaan dengan total aktiva tetap yang tinggi dapat menggunakan aktiva tetapnya sebagai jaminan dalam mengajukan pinjaman.

Perusahaan property and real estate yang terdaftar di Bursa Efek Indonesia selama tahun 2014 - 2018 memiliki proporsi aktiva tetap yang jauh lebih tinggi dibandingkan dengan aktiva lancarnya dengan nilai yang berkisar antara $0.14 \%$ sampai $26.20 \%$, hal tersebut dikarenakan perusahaan property and real estate banyak melakukan investasi pada tanah dan bangunan. Besarnya aktiva tetap yang dimiliki oleh perusahaan property and real estate yang terdaftar di Bursa Efek Indonesia selama tahun 2014 - 2018 memberikan manfaat karena dapat menunjukkan kemampuan perusahaan dalam menjamin pinjaman utangnya, sehingga dapat meningkatkan kepercayaan kreditur dalam memberikan pinjaman utang kepada perusahaan.

$\mathrm{H}_{3}$ dalam penelitian ini adalah pertumbuhan perusahaan berpengaruh positif dan signifikan terhadap struktur modal. Hasil pengujian menunjukkan variabel pertumbuhan perusahaan memiliki nilai $\beta$ sebesar 0.008 serta nilai signifikansi uji $\mathrm{t}$ sebesar $0.048<\alpha=0.05$. Nilai tersebut menunjukkan bahwa pertumbuhan perusahaan berpengaruh positif dan signifikan terhadap struktur modal perusahaan property and real estate yang terdaftar di Bursa efek Indonesia selama tahun 2014 - 2018, sehingga $\mathrm{H}_{3}$ dalam penelitian ini diterima.

Hasil pengaruh pertumbuhan perusahaan terhadap struktur modal pada penelitian ini mendukung hasil penelitian yang ditemukan oleh Vuran et al. (2017), Karacaer et al. (2016), Dewi \& Candradewi (2018), serta Daskalakis et al. (2014) yang menyatakan bahwa pertumbuhan perusahaan berpengaruh positif dan signifikan terhadap struktur modal. Hasil yang membuktikan adanya pengaruh positif dan signifikan antara pertumbuhan perusahaan dan struktur modal tersebut juga sejalan dengan perspektif pecking order theory yang menyatakan bahwa perusahaan yang memiliki tingkat pertumbuhan yang tinggi akan lebih mengandalkan kepada modal eksternal dikarenakan pertumbuhan perusahaan akan memicu kebutuhan modal perusahaan yang semakin tinggi.

Pertumbuhan perusahaan property and real estate yang terdaftar di Bursa Efek Indonesia selama tahun 2014 - 2018 tergolong sangat cepat dengan nilai yang berkisar antara $-16.42 \%$ sampai $103.74 \%$. Pertumbuhan perusahaan yang diukur dengan pertumbuhan total aktiva membuat perusahaan merasa pendanaan secara internal saja tidak mampu untuk memenuhi kebutuhan modal perusahaan yang semakin meningkat dalam melakukan ekspansi ataupun investasi pada aktivanya, sehingga perusahaan masih memilih untuk meningkatkan penggunaan utang dalam struktur modalnya.

Terkait implikasi penelitian, hasil penelitian ini mampu memberikan bukti empiris yaitu profitabilitas berpengaruh positif tidak signifikan terhadap struktur 
modal serta struktur aktiva dan pertumbuhan perusahaan berpengaruh positif signifikan terhadap struktur modal. Hasil penelitian ini menunjukkan adanya pengaruh positif tidak signifikan antara profitabilitas terhadap struktur modal, serta pengaruh positif dan signifikan antara struktur aktiva serta pertumbuhan perusahaan terhadap struktur modal. Hasil tersebut dapat digunakan oleh manajer sebagai bahan pertimbangan dalam penentuan struktur modal perusahaan agar nantinya seluruh kebutuhan investasi dan aktivitas perusahaan dapat tercukupi. Hasil penelitian ini juga dapat menjadi bahan pertimbangan bagi investor yang ingin melakukan investasi pada sub sektor property and real estate di Bursa Efek Indonesia.

\section{SIMPULAN}

Berdasarkan hasil analisis yang telah diuraikan mengenai determinasi struktur modal pada perusahaan sub sektor property and real estate yang terdaftar di Bursa Efek Indonesia selama tahun 2014 - 2018, maka diperoleh kesimpulan yaitu profitabilitas tidak berpengaruh signifikan terhadap struktur modal. Profitabilitas perusahaan property and real estate yang terdaftar di Bursa Efek Indonesia selama tahun 2014 - 2018 cenderung sangat kecil, sehingga tidak berdampak banyak terhadap struktur modal perusahaan tersebut. Struktur modal perusahaan akan tetap meningkat ketika profitabilitas perusahaan mengalami fluktuasi.

Struktur aktiva berpengaruh positif dan signifikan terhadap struktur modal. Perusahaan sub sektor property and real estate yang terdaftar di Bursa Efek Indonesia selama tahun 2014 - 2018 memiliki jumlah aktiva tetap yang jauh lebih tinggi dibandingkan aktiva lancarnya dengan nilai yang berkisar antara $0.14 \%$ sampai $26.20 \%$. Besarnya aktiva tetap yang dimiliki oleh perusahaan dapat menjamin pinjaman utangnya, sehingga dapat meningkatkan kepercayaan kreditur dalam memberikan pinjaman utang kepada perusahaan. Pertumbuhan perusahaan berpengaruh positif dan signifikan terhadap struktur modal. Pertumbuhan perusahaan property and real estate yang terdaftar di Bursa Efek Indonesia selama tahun 2014 - 2018 tergolong sangat cepat dengan nilai yang berkisar antara $16.42 \%$ sampai $103.74 \%$. Pertumbuhan perusahaan yang cepat membuat perusahaan merasa pendanaan secara internal saja tidak mampu untuk memenuhi kebutuhan modal perusahaan yang semakin meningkat dalam melakukan ekspansi ataupun investasi pada aktivanya, sehingga perusahaan masih memilih untuk meningkatkan penggunaan utang dalam struktur modalnya.

Perusahaan perlu memperhatikan struktur aktiva dan pertumbuhan perusahaan dikarenakan kedua variabel ini memiliki pengaruh positif dan signifikan terhadap struktur modal, sehingga perusahaan dapat menentukan komposisi pendanaannya agar menghasilkan struktur modal yang optimal. Penelitian ini hanya menggunakan variabel profitabilitas, struktur aktiva, dan pertumbuhan perusahaan sebagai variabel bebas. Penelitian selanjutnya diharapkan dapat menambah variabel bebas yang lain seperti ukuran perusahaan, tingkat penjualan, ataupun pajak, serta menambah jumlah perusahaan dari industri lain guna memberikan hasil penelitian yang lebih baik. 


\section{REFERENSI}

Acaravci, S. K. (2015). The Determinants of Capital Structure: Evidence from the Turkish Manufacturing Sector. International Journal of Economics and Financial Issues, 5(1), 158-171.

Ahmad, G. N., Lestari, R., \& Dalimunthe, S. (2017). Analysis of Effect of Profitability, Assets Structure, Size of Companies, and Liquidity to Capital Structure in Mining Companies Listed in Indonesia Strock Exchange Period 2012-2015. Jurnal Riset Manajemen Sains Indonesia, 8(2), 339-354. https://doi.org/https://doi.org/10.21009/JRMSI.008.2.09

Alipour, M., Mohammadi, M. F. S., \& Darakhshan, H. (2015). Determinants of Capital Structure: An Empirical Study of Firms in Iran. International Journal of Law and Management, 57(1), 53-83. https://doi.org/http://dx.doi.org/10.1108/IJLMA-01-2013-0004

Apsari, G. A. P. I., \& Dana, I. M. (2018). Pengaruh Profitabilitas, Struktur Aktiva, dan Size terhadap Struktur Modal Pada Perusahaan Barang Konsumsi di BEI. E-Jurnal Manajemen Unud, 7(12), 6842-6871.

Ariyani, H. F., Pangestuti, I. R. D., \& Raharjo, S. T. (2018). The Effect of Asset Structure, Profitability, Company Size, and Company Growth on Capital Structure (The Study of Manufacturing Companies Listed on the IDX for the Period 2013 - 2017). Jurnal Bisnis STRATEGI, 27(2), 123 - 136.

Berkman, A. N., skenderoğlu, O., Karadeniz, E., \& Ayyildiz, N. (2016). Determinants of Capital Structure: The Evidence from European Energy Companies. International Journal of Business Administration, 7(6), 96-106. https://doi.org/http://dx.doi.org/10.5430/ijba.v7n6p96.

Bhawa, I. B. M. D., \& Dewi, M. R. (2015). Pengaruh Ukuran Perusahaan, Likuiditas, Profitabilitas, dan Risiko Bisnis Terhadap Struktur Modal Perusahaan Farmasi. E-Jurnal Manajemen Unud, 4(7), 1949-1966.

Brigham, E. F., \& Houston, J. F. (2014). Dasar-dasar Manajemen. Keuangan. Jakarta: Salemba Empat.

Daskalakis, N., Eriotis, N., Thanou, E., \& Visiliou, D. (2014). Capital Structure and Size: Evidence Accros the Broad Spectrum of SMEs. Managerial Finance, 40(12), 1207-1222.

Deviani, Y. M., \& Sudjarni, L. K. (2018). Pengaruh Tingkat Pertumbuhan, Struktur Aktiva, Profitabilitas, dan Likuiditas terhadap Struktur Modal Perusahaan Pertambangan di BEI. E-Jurnal Manajemen Unud, 7(3), 1222-1254.

Dewi, M. A. P., \& Candradewi, M. R. (2018). Pengaruh Pertumbuhan Perusahaan dan Profitabilitas terhadap Struktur Modal dan Nilai Perusahaan. E-Jurnal Manajemen Unud, 7(8), 4385-4416.

Dewi, P. A. G. K., Wiksuana, I. G. B., \& Rahyuda, H. (2017). Variabel-variabel 
Penentu Struktur Modal Perusahaan Non Keuangan di Bursa Efek Indonesia. Matrik Jurnal Manajemen, Strategi Bisnis, Dan Kewirausahaan, 11(1), 92104.

Gwatidzo, T., Ntuli, M., \& Milo, M. (2016). Capital Structure Determinants in South Africa: A Quantile Regression Approach. Journal of Economic and Financial Sciences, 9(1), 275-290.

Hadi, A. R. A., Rehan, R., Zafar, S., \& Khattak, M. A. (2018). Capital Structure Determinants of Firms at Bursa Malaysia. International Journal of Engineering \& Technology, 7(4), 86-90.

Juliantika, N. L. A. A. M., \& Rusmala, D. (2016). Pengaruh Profitabilitas, Ukuran Perusahaan, Likuiditas, dan Risiko Bisnis terhadap Struktur Modal Pada Perusahaan Property Dan Realestate. E-Jurnal Manajemen Unud, 5(7), 4161 -4192 .

Kabeer, M. A., \& Rafique, A. (2018). The Determinants of Capital Structure: Evidence from Pakistani Manufacturing Company. Journal of Banking and Finance Management, 1(3), 1-16.

Karacaer, S., Huseyin, T., \& Gulec, O. F. (2016). Determinants of Capital Structure: An Application on Manufacturing Firms in Borsa Instanbul. International Academic Institute for Science and Technology, 3(2), 47-59.

Kythreotis, A., Nouri, B. A., \& Soltani, M. (2018). Determinants of Capital Structure and Speed of Adjustment: Evidence from Iran and Australia. International Journal of Business Administration, 9(1), 88 - 113. https://doi.org/https://doi.org/10.5430/ijba.v9n1p88

M'ng, J. C. P., Rahman, M., \& Sannacy, S. (2017). The Determinants of Capital Structure: Evidence from Public Listed Companies in Malaysia, Singapore, and Thailand. Cogent Economics \& Finance, 5(1), 1-20. https://doi.org/https://doi.org/10.1080/23322039.2017.1418609

Maryanti, E. (2016). Analisis Profitabilitas, Pertumbuhan Perusahaan, Pertumbuhan Penjualan, dan Struktur Aktiva terhadap Struktur Modal pada Perusahaan Sektor Industri Barang Konsumsi yang Terdaftar di Bursa Efek Indonesia. Riset Akuntansi Dan Keuangan Indonesia, 1(2), 143-151.

Ngjeliu, A. (2018). The Determinants of Capital structure: Evidence from Listed Companies in Balkan Countries. Academic Journal of Business, Administration, Law and Social Sciences, 4(1), 18 - 34.

Nnadi, M. (2016). Accounting Factors Affecting the Capital Structure in the Asian Economic Community. International Journal of Accounting Research, 5(1), 1 - 9. https://doi.org/10.4172/2472-114X.1000139

Sartono, A. (2014). Manajemen Keuangan:Teori dan Aplikasi (4th ed.). Yogyakarta: BPFE. 
Sofat, R., \& Singh, S. (2017). Determinants of Capital Structure: An Empirical Study of Manufacturing Firms in India. International Journal of Law and $\begin{array}{llll}\text { Management, } & 59(6), & 1029 & -\end{array}$ https://doi.org/https://doi.org/10/1108/IJLMA-05-2016-0051

Sudarmika, G. Y., \& Sudirman, M. S. N. (2015). Pengaruh Profitabilitas, Pertumbuhan Perusahaan, Struktur Aktiva, dan Pajak terhadap Struktur Modal. E-Jurnal Manajemen Unud, 4(9), 2857-2885.

Tandya, C. (2015). The Capital Structure Determinants of Indonesia Publicly Listed Firms. IBuss Management, 3(2), 19-27.

Ulzanah, A. A., \& Murtaqi, I. (2015). The Impact of Earnings Per Share, Debt to Equity Ratio, and Current Ratio Towards the Profitability of Companies Listed in LQ45 from 2009 to 2013. Journal of Business and Management, $4(1), 18-27$.

Violita, R. Y., \& Sulasmiati, S. (2017). Pengaruh Struktur Modal terhadap Profitabilitas (Studi Pada Perusahaan Food and Beverages and Terdaftar di BEI tahun 2013-2016). Jurnal Administrasi Bisnis, 51(1), 138-144.

Vuran, B., Taş, N., \& Adiloğlu, B. (2017). Determining the Factors Affecting Capital Structure Decisions of Real Sector Companies Operating in ISE. International Journal of Economics and Finance, 9(8), 25-32.

Wiagustini, N. L. P., Ramantha, I. W., Sedana, I. B. P., \& Rahyuda, H. (2017). Indonesia's Capital Structure: Pecking Order Theory or Trade-Off Theory. International Journal of Applied Business and Economic Research, 15(16), 119-131. 